The sighting of my first Ross's Gull, over two decades ago, was reported in an article on the birds of northern Baffin Island by Renaud et al. ${ }^{2}$ Renaud included me in the authorship, though that honour was never as close to my heart as that orange stain. With hesitation, I stuffed the sweater into the garbage bag.

What are the odds, I wondered, of finding the second Ross's Gull of my life near the Wise Place. I imagined Harris computing the standard deviation, dividing by that infernal eight, and laughing with glee. He would have enjoyed the irony and the host of factors that brought the little pink gull from Siberia in from the cold.

\section{Acknowledgements}

Thanks to Brent Honeker for backing up in time, and to Wayne Renaud and Gavin
Johnston for their comments and the fine memories. Anna Leighton kept me in line, as usual.

* The "Wise Slough", located beside the Wise family homestead, seven miles northeast of Luseland, was a wetland conservation project, initiated by my father, R.G. Finley, in the mid-sixties.

1. RENAUD, W. and D. RENAUD. 1975 . Birds of the Rosetown-Biggar District, Saskatchewan. Saskatchewan Natural History Society Special Publication No. 21. Regina.

2. RENAUD, W. G. JOHNSTON and K. J. FINLEY. 1981. The avifauna of Pond Inlet region, NWT. A spectacular mountain wilderness with a diverse arctic avifauna. American Birds 35 (2): 119-129,132-134.

\title{
URBAN-NESTING MERLINS AND COOPER'S HAWKS IN WEYBURN, SK
}

\author{
KELLY KOZIJ, 803 Coteau Avenue, Weyburn, SK S4H 0H1
}

\section{Merlins}

In the spring of 2002, I undertook to determine the numbers and nesting success of Merlins within the city limits of Weyburn, Saskatchewan. I had developed an interest in Merlins near Hendon, SK in the late 1980 s. Following my relocation to Weyburn in the fall of 1997, I observed Merlins in various areas of the city, which piqued my curiosity.

The majority of Merlin nests seemed to be concentrated within an area I describe as 'the older part of town'. This area is characterized by older buildings and more mature stands of trees as opposed to the more recently developed 'newer parts of town', with younger, shorter and thinner trees.

The trees in Weyburn are a mixture of deciduous and coniferous species planted by homeowners and the City Parks Department since the community was first formed at the end of the 19th century. An estimate of the ratio of the plantings on city-owned property is $25 \%$ coniferous and $75 \%$ deciduous trees (Claude Morin, City of Weyburn Parks Department, pers. comm.). No estimate is available for private property. 

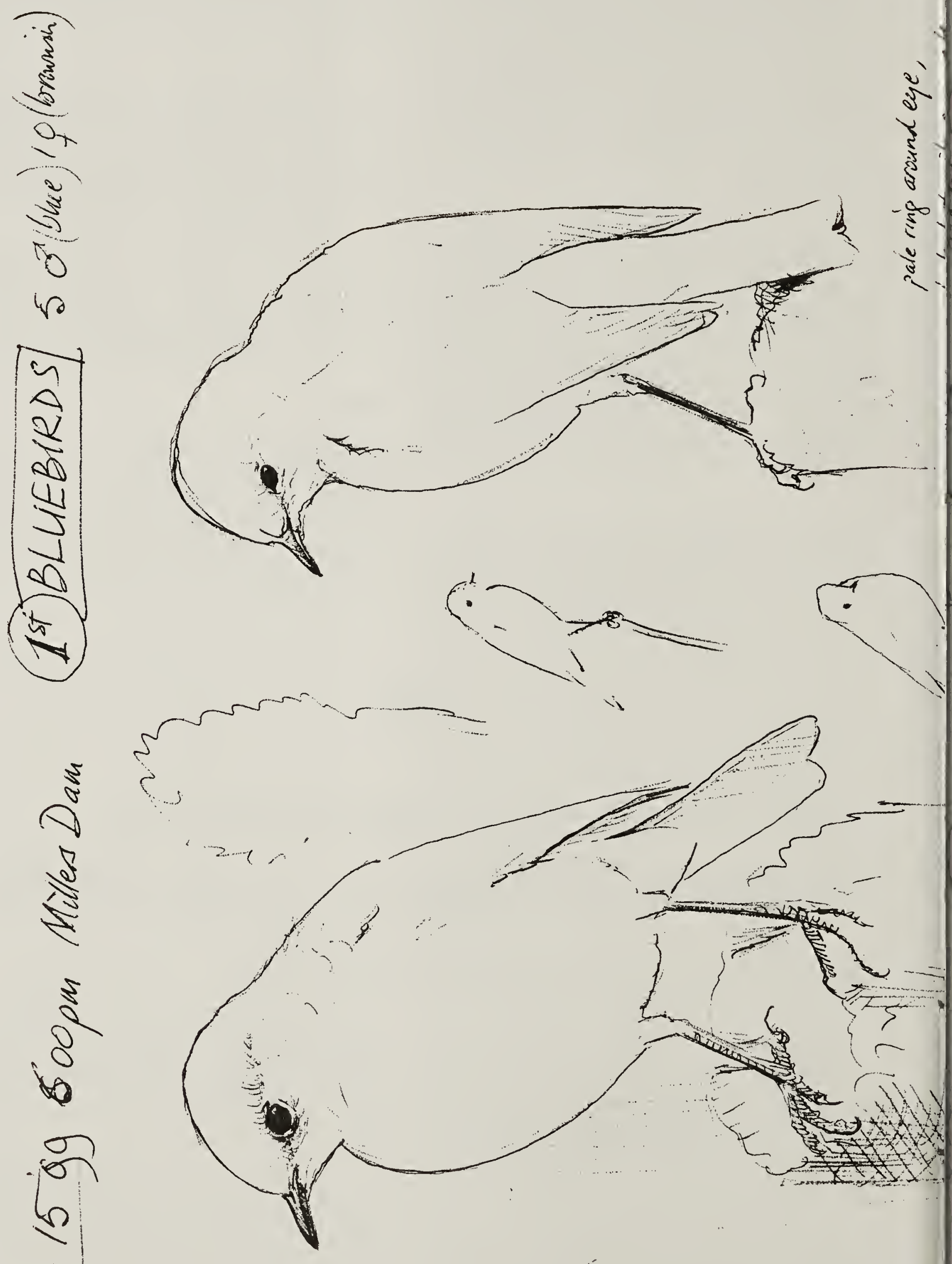

$\frac{v}{v}$

(*) 


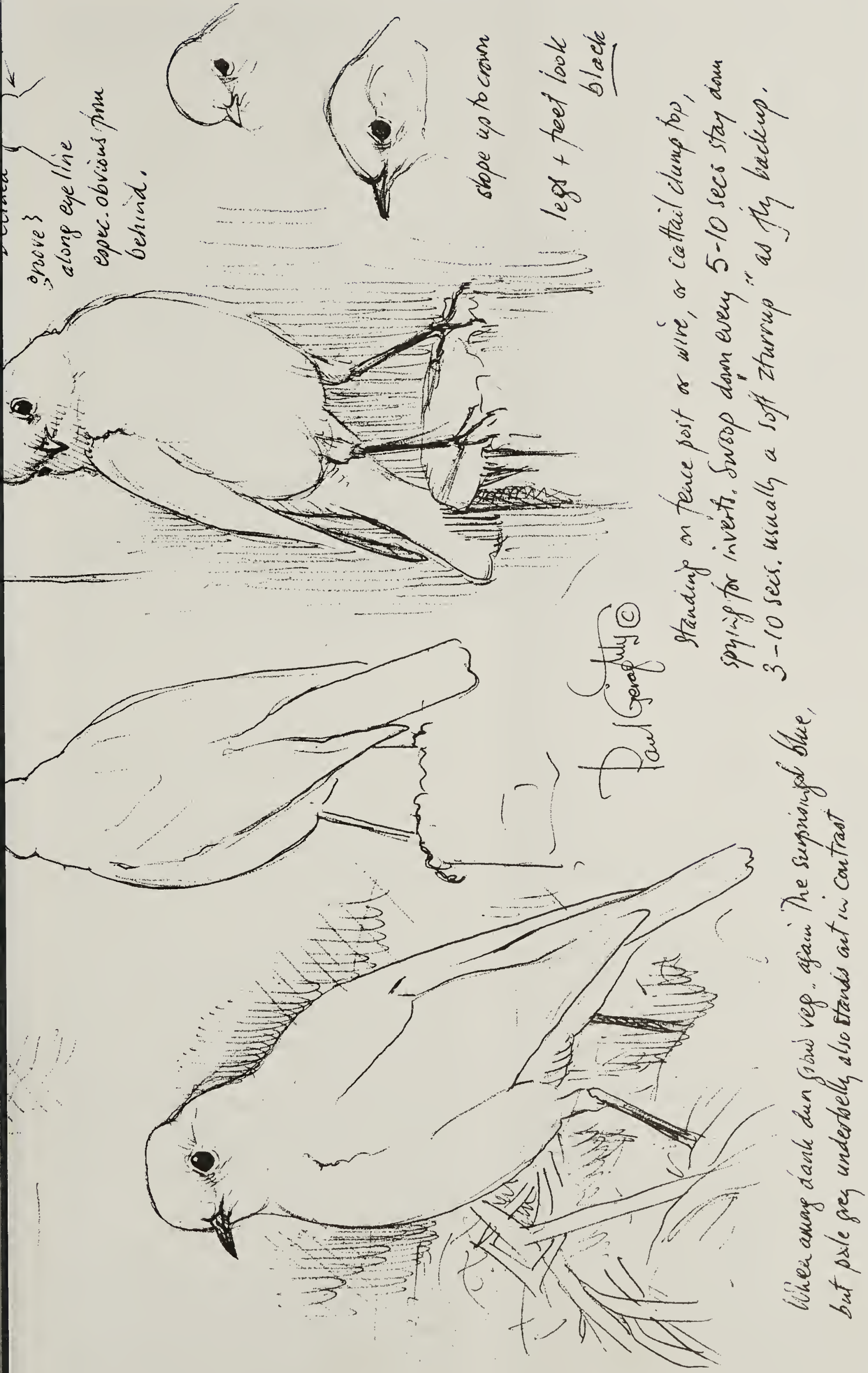


The area of the city covered in this survey was approximately $5.0 \mathrm{~km}^{2}$ and included residential, commercial and industrial areas, as well as parks (both natural and manmade). I focussed the greatest effort on 'the older part of town', a residential area of approximately $2.0 \mathrm{~km}^{2}$ which was the primary search area, and two locations, the secondary search area, slightly outside the main residential area, which have similar tree cover and added $0.78 \mathrm{~km}^{2}$ in total to the search area.

Beginning in early May, I cycled through the city, primarily where Merlins had been observed in previous years, listened for their vocalizations, and observed possible nest locations. Merlin vocalizations were easy to hear while cycling, and paved streets made travelling quick, easy and quiet. I located five nesting pairs within the primary search area and later found an unusually quiet sixth pair. There was no nesting activity noted in either of the two secondary search areas despite nesting activity in at least one previous year.

A seventh pair of Merlins was also observed within the primary study area but no active nest was located. This pair's activity seemed to be centred around a tall spruce where a remnant of an old crow nest was present. This pair stayed on the territory but the lack of a satisfactory nest site may have precluded nesting. This pair was $0.28 \mathrm{~km}$ and $0.48 \mathrm{~km}$ from each of the two nearest neighbouring nests.

Once the actual nest trees were pinpointed, I monitored activity around each individual nest area on almost a daily basis. The absence of the male and female for several days in succession at one nest site in late June led me to believe the nest had failed. Upon asking the property owner for permission, and climbing the spruce tree, I found the nest had shifted on its supporting branches, spilling the contents over the edge; fragments of broken eggshells and the carcass of one tiny young (less than 1 week old) were found on the ground below the nest. This nest site had been abandoned between June 15 and June 22.

This development, along with young visible from the ground in two other nests, prompted me to seek permission to climb to the other five nests to determine the number of young that had hatched. On June 24, I found 21 young in the five nests, (three, four, four, five and five) (see photo on page 25). One nest with four young also contained an unhatched egg, while the other nest with four young was later found to have the partial remains of another chick on the ground below the nest.

A strong windstorm on June 29 blew three of five young from one nest, resulting in their death; on July 14, a fourth young fell from this nest and it too died. Seventeen young are believed to have fledged from these nests with thirteen of them banded for future identification.

Each pair of Merlins nested in an abandoned crow nest in a spruce tree, with the average nest height $11.1 \mathrm{~m}$ (range 9.8 to $14.5 \mathrm{~m}$ ). When plotted on a map, five of the nests were aligned in a crescent shape with the sixth located further to the east. The distance between adjacent nests in the crescent, as measured by GPS, ranged from $0.29 \mathrm{~km}$ to $0.70 \mathrm{~km}$ (average $0.49 \mathrm{~km}$ ). The nest to the east averaged $0.88 \mathrm{~km}$ from each of the others (range $0.67 \mathrm{~km}$ to $1.16 \mathrm{~km}$ ). Following the failure of one nest in June, I suspect but cannot confirm that the mated pair shifted their centre of activity $0.19 \mathrm{~km}$ to another area where the female continued to receive food from the male for approximately two weeks before they dispersed to an unknown area.

The nesting density of merlins, 6 pairs/ $2.78 \mathrm{~km}^{2}$, in my study area of Weyburn during 2002 is comparable to the density in a Saskatoon study which, in 1989 , reached 25.4 pairs $/ 100 \mathrm{~km}^{2}{ }^{1}$ As trees in 'the newer 


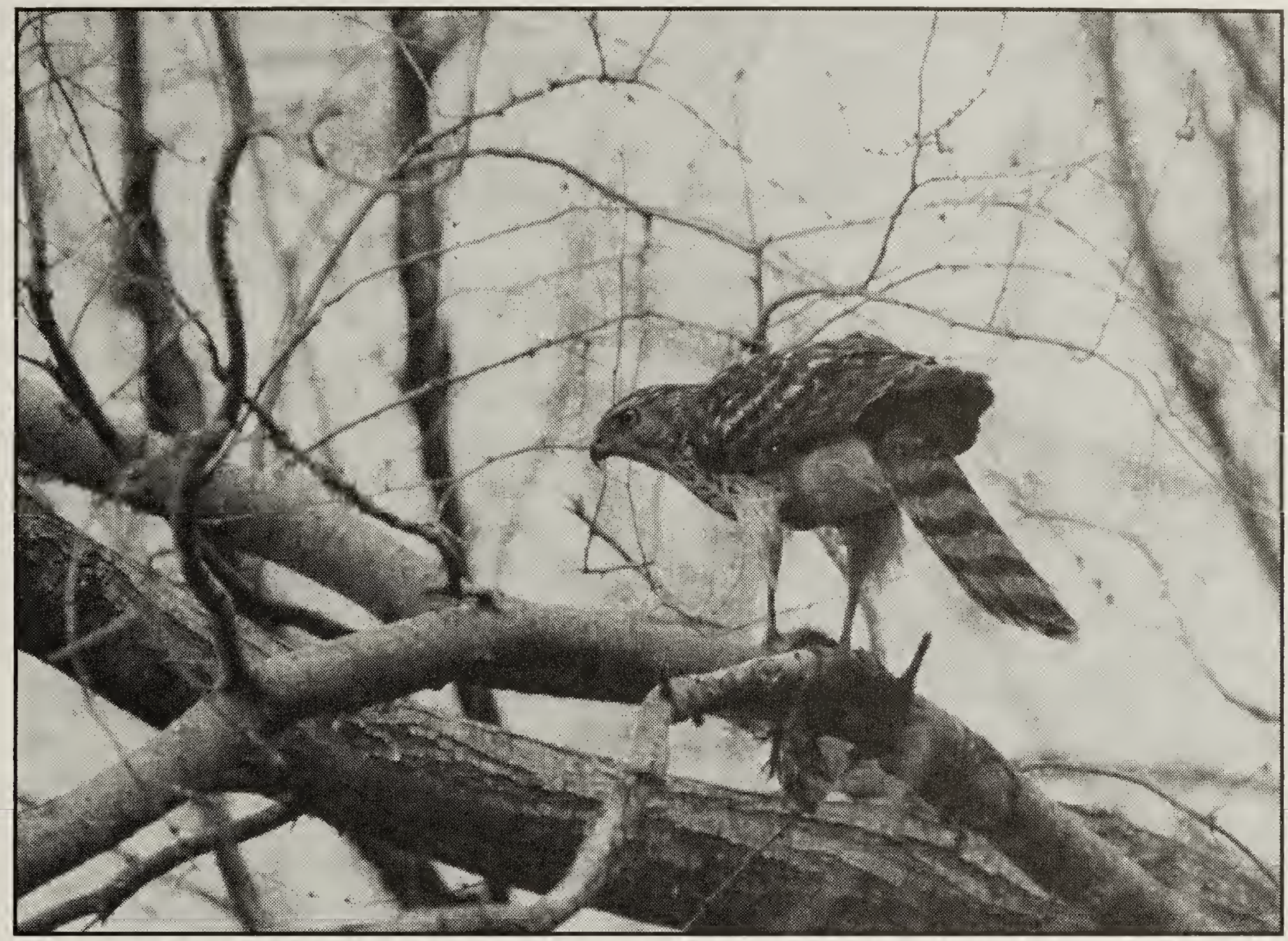

Figure 2. Female Cooper's Hawk with squirrel prey, 2002

Kelly Kozij

parts of town' become more mature an additional $1.64 \mathrm{~km}^{2}$ of potential nesting territory will be added to the area currently utilized by Weyburn Merlins.

\section{Cooper's Hawks}

In 2002, I also discovered two pairs of Cooper's Hawks nesting within Weyburn city limits.

A male Cooper's Hawk was seen almost daily from late April until May 6 when a female, still in juvenile plumage (see front cover), joined him. These two birds frequently perched in a back lane where they often were seen with various prey items including a robin and either ground or fox squirrels (I was unable to make a positive identification of the species of squirrel) (Fig. 2).

The nest, only $0.27 \mathrm{~km}$ from the nearest pair of Merlins, was $9.5 \mathrm{~m}$ high in a spruce tree immediately behind a house. It was discovered on May 20, and four eggs were present on June 22. One downy young was visible moving beneath the female on June
26, with four young in the nest on July 7. These young hawks were banded on July 10 and, after fledging, were seen in the vicinity of the nest throughout August. During this time they were fed by the adult hawks and, in one case in early evening, were feeding on a Hoary Bat. It is not known whether the bat was caught in flight or taken off its day roost.

These hawks became remarkably tolerant of human activity for a species I had always considered to be rather shy of people. During my initial observations, if the birds knew I was watching them, I had to make very slow deliberate moves, even at a distance, to avoid startling either bird into flight. Pedestrians or cyclists who acted as if the birds had not been seen could pass within eight to ten metres. The nest site was only $13.5 \mathrm{~m}$ from the centre of the adjacent street and its associated traffic, both vehicular and pedestrian. An adjoining street, $0.13 \mathrm{~km}$ south of the nest location, has an average traffic count of 2400 vehicles per day, while to the east, on another street $0.2 \mathrm{~km}$ away, 3000 
vehicles pass by daily (Bob Kinash, City of Weyburn engineer, pers. comm.).

A second pair of nesting Cooper's Hawks was found with three young on July 21 , on the grounds surrounding the Souris Valley Hospital, $2.35 \mathrm{~km}$ from the previously mentioned nest. These two nests are the second and third Cooper's Hawk nests found in Weyburn, the first being found in 2000 , also on the Souris Valley property (Martin Bailey, pers. comm.). These three nests are the only urban nesting Cooper's Hawks that I am aware of in Saskatchewan. There was some speculation about Cooper's Hawks nesting within Wascana Park in Regina in 2001 where fledged young were observed and attacking behaviour noted. And in 2002, two pairs stayed in Regina into late spring, leading to speculation that nesting would occur but apparently they later left (Bob Luterbach, pers. comm.).
Cooper's Hawks may be adapting to urban environments as they have been nesting for several years at Oak Park in central Minot, North Dakota, and also within Victoria, BC. Last year Medicine Hat, AB had its first nest ever at Police Point on the edge of a busy a golf course (Bob Luterbach, pers. comm.).

\section{Acknowledgments}

I would like to thank those individuals whose interest and patience contributed to this survey: Martin Bailey, Mark Brigham, Faye Ferner, Bob Luterbach, Lynn Oliphant, SERM Weyburn staff, and each of the homeowners who allowed me access to their property. C. Stuart Houston provided advice and information and bands for the young birds, and encouraged me to write this report.

1. SODHI, N.S. ET AL. 1992 Breeding ecology of urban Merlins Canadian Journal of Zoology Vol. 701477 - 1482

\section{$\mathcal{Y}$}

\section{PRAIRIE WARBLER IN SASKATOON - THE SECOND RECORD FOR SASKATCHEWAN}

\section{ROBERT WAPPLE, 740 4th Street East, Saskatoon, SK S7H 1K2}

Around 1600 h on Friday, October 18, 2002, I saw a smallish bird flitting among the lower branches of the aspens just outside my office window at Innovation Place in Saskatoon. At first, I assumed it was a Yellow-rumped Warbler but noticed that it was quite bright yellow and had some black streaking on its sides, a large amount of white on the outer edges of the tail, and no yellow on the rump. On closer inspection, I noted that the bird had an olive green back and wings, whitish undertail coverts, bright yellow throat, chest, and facial markings. Most striking were the distinct rows of bold black streaks down each flank. It was active as it hovered to pluck insects off of the undersides of the leaves still on the trees.

Realizing that I was looking at something unfamiliar and unusual, I started to eliminate other possible yellowish, streaked warblers. The bright yellow front and bold streaking on the sides suggested a Magnolia Warbler but the tail markings ruled it out. The indistinct olive-green wingbars ruled out 